\title{
DEUX POÈMES DOS POEMAS
}

\section{Laurence BREYSSE-CHANET}

Lumière d'or du désir

et l'obscur du bois.

Des chemins de rappel,

la pierre court au torrent

et derrière le rideau s'étoile un songe.

Voici l'étang, imprenable château.
Luz de oro del deseo

y lo sombrío del bosque.

Vias de rápel,

la piedra persigue el torrente

y tras la cortina estrellea un sueño.

He aquí el estanque, inexpugnable castillo. 
268 Tropelías. Revista de Teoría de la Literatura y Literatura Comparada, 29 (2018) Laurence Breysse-Chanet

Le visage du vent

mord les limites du temps.

Anneau d'or sur les yeux,

l'espace estompe ton regard

et s'abandonne à la brume du monde.

Sur les ronces ta main se perd,

l'écho vient lui tisser un gant.

Râpeuse la pierre frôle la vie,

son énigme renvoie le soleil.
El rostro del viento

muerde los bordes del tiempo.

Anillo de oro en los ojos,

el espacio difumina tu mirada

y se entrega a la bruma del mundo.

Por las zarzamoras tu mano se pierde,

el eco acude a tejerle un guante.

Áspera la piedra roza la vida,

su enigma rebota el sol. 